\title{
Editorial: Stars in the West
}

'Marriage is a ghastly public confession of a purely private intention.' Bernard Shaw's aphorism is recalled to mind by the public appearances, interviews and photo-opportunities with which some migrant philosophers have enveloped and sometimes obscured their reasons and motives.

The migration is only one of a number of recent events which have brought philosophy and philosophers to public notice. There have been noisy debates before and after the closures of departments of philosophy in a number of universities. The initials NCP used to mean only 'National Car Parks' but now they also stand for the National Committee for Philosophy that has been founded by the threatened 'profession' to protect itself and its members. Much air and space and television time were given to last year's World Congress of Philosophy in Brighton. This year there have been celebrations of the centenary of the birth of Wittgenstein, and tributes to the late Professor Sir Alfred Ayer.

For philosophy, many of its practitioners think, no news is good news. Socrates sheltered behind a wall from the winds of the world so that his thinking could be calmer and hence more powerful, both in itself and in its eventual effects on that same stormy world. Wittgenstein declared that the philosopher is not a citizen of any community of ideas, and that that is what makes him a philosopher. Still less would he have wished the trade of the thinker to form its own guild and to seek solidarity with a party line. The Platonic distinction between the philosopher and the rhetorician or demagogue retains its validity, and when philosophers are propagandists or politicians they are as likely as any other interest group to think and speak in slogans and shibboleths.

To say this is not to ask philosophers to take no part in the defence of their way of life against its enemies and against some of its more muddled friends; still less is it to ask them to renounce all concern with public affairs more generally. It is to remind them of the character and effects of the instruments and skills that they should bring from their more specialist activities into the public arena. It is to ask that they should not forget in politics any more than in epistemology or philosophical logic to use the sharp eye for a distinction that will save them from communities of ideas and their stifling solidarities. This plea must be all the more pressing when the issues at stake are themselves philosophical as well as practical, as they are when they touch on the 


\section{Editorial}

place of philosophy in the human world. Let us think of some of the distinctions that are liable to be obscured in the noise of battle.

It is one thing to give sympathy and support to the members of the closed departments, and to the younger professional philosophers whose future as such is threatened by the fall in the number of academic vacancies, and quite another to link the health of philosophy generally with particular views and practices about admissions and appointments, or to think that more will mean better. A department with five teaching members is now under suspicion of 'non-viability'. No such complaint was or is made against an institution whose staff in 1945 consisted only of Wittgenstein, Broad, Wisdom, Ewing and Braithwaite.

When we are defending ourselves against public criticism and public policies we must distinguish between the intrinsic and the instrumental value of philosophy. Too much emphasis on medical ethics, or on the value of philosophy graduates as civil servants or entrepreneurs, or of philosophy dons as members of committees and commissions, will implicitly involve us in terms of debate under which the humanities in general will be theoretically misunderstood and practically imperilled.

As no member or officer of this Institute will forget, we need to attend to the place of philosophy in the wider life of our society, and not only to its place in universities and colleges. To neglect this wider concern would be to foster what is already a widespread superstition: that philosophical work cannot be disciplined and rigorous unless it is formal and technical. It is nowadays more fitting than it used to be that a type of visa commonly issued to transatlantic migrants was originally instituted to regulate the admission into the United States of persons with certain scarce and esoteric skills, such as exotic cooks and circus acrobats. 